\title{
Immunohistochemical localization of pregnancy-associated plasma protein-A in the male genital tract
}

\author{
A.M.Schindler ${ }^{1}$, A.Dayer and P.Bischof \\ Instutute of Pathology, CHUV, CH-1011 Lausanne and ${ }^{2}$ Department of \\ Obstetrics and Gynaecology, University of Geneva, Switzerland \\ 'Author to whom correspondence should be addressed
}

Pregnancy-associated plasma protein-A (PAPP-A) has been found in seminal fluid at concentrations 10-20 times higher than in plasma. This observation prompted us to undertake a morphological study of the male genital tract with the aid of the immunoperoxidase technique. Immunoreactive cells were found among the Leydig cell population, as well as among the epithelium of the rete testis, the head of the epididymis and the seminal vesicles. The relatively small number of weakly staining epithelial cells leaves open the question of whether PAPP-A is excreted by these cells or whether an active transfer mechanism - possibly in the seminal vesicles - is at work, the Leydig cells increasing the plasma concentration locally, by secretion of PAPP-A into the circulation.

\section{Introduction}

Pregnancy-associated plasma protein-A (PAPP-A) is one of the recently discovered proteins associated with pregnancy (Lin $e t$ al., 1974). It is found in highest concentrations in maternal plasma but much lower concentrations of this protein are also found in the plasma of non-pregnant women and of men (Bischof et al., 1982a, 1982b, 1983). As other placental proteins, such as human chorionic gonadotrophin (HCG), human placental lactogen (HPL), Schwangerschaftsprotein $1\left(\mathrm{SP}_{1}\right)$ and placental protein $5\left(\mathrm{PP}_{5}\right)$, PAPP-A has also been found in seminal plasma (Bischof et al., 1983). According to Bischof et al. (1983), the physicochemical and immunochemical properties of seminal plasma PAPP-A are identical to pregnancy plasma PAPP-A. The biological function of PAPP-A is still unknown. An immunosuppressive activity, first described in vitro for plasma PAPP-A from pregnant women, has been confirmed for seminal fluid PAPP-A (Martin-du-Pan et al., 1983). These observations, however, were not confirmed by others (McIntyre et al., 1981; Stimson, 1981) using different assays and different PAPP-A preparations. The origin of PAPP-A is largely unknown. In the female, secretion by the placenta (Bischof et al., 1984; Lin et al., 1974, 1976), the decidua (Bischof et al., 1984; Schindler et al., 1984), as well as the endometrium (Bischof $e t$ al., 1982a, 1982b) have been proposed as possible sources.

The present immunohistochemical study has been undertaken in order to study the tissue distribution of PAPP-A in the male genital tract.

\section{Materials and methods}

The material was obtained either from biopsies (testicular tissue), from surgical specimens (testes from gonadectomies, seminal vesicles from total cystectomy specimens) or from autopsies performed within $2-4 \mathrm{~h}$ after death. In addition to human material, seven gonads from fetal and/or neonatal thesus monkeys were studied. Small fragments or tissue slices were fixed in Bouin's fixative, embedded in paraffin, and immunoperoxidase stained as previously described (Lin et al., 1976). In short, rabbit anti-human serum raised against PAPP-A (Bischof, 1979) was diluted at 1:160; in parallel sections, commercially available PAPP-A (DAKO, Glostrup, Denmark) was used at a concentration of 1:300. Both antisera when used in the radioimmunoassay detected immunoreactive PAPP-A in seminal plasma. The indirect peroxidase - antiperoxidase method was used. Control sections were treated with anti-PAPP-A senum previously absorbed with purified PAPP-A (immobilized on a heparin-Sepharose column).

\section{Results}

Material was obtained from 16 adult males and from seven fetuses. Table I shows the type and the number of organs examined, as well as the results.

In the human material, the only tissue reacting strongly and consistently with PAPP-A anti-serum were the Leydig cells (Figure 1). Positive cells were found with both anti-sera in fetal, in infantile, as well as in the adult testes. The Leydig cells were composed of a double population, one of which stained negatively, the other positively, some rare cells showing an intermediate reaction. The cytoplasm of a given cell was uniform in its staining reaction. The number of positive cells varied from testis to testis and from one place to another. It was definitely higher in adults than in fetuses, where positive cells were frequently localized to one area; PAPP-A reactive cells comprise -5 to 1 in 10 cells. Cytologically, positive and negative cells were indistinguishable.

In monkey testes, the same pattern was observed; the staining of Leydig cells was, however, weaker.

Along the excretory canal in the human male, some epithelial cells of the rete testis, of the proximal epididymis and of the seminal vesicles showed positive staining. These cells, randomly distributed, were not abundant and showed a much weaker reaction than did the Leydig cells. In the rete, some positive cells were found in seven out of eight cases studied (Figure 2), including a fetus. In the epididymis, positive cells were rare and found only in the most proximal segments (Figure 3). Ten out of 11 adult cases, in which these proximal segments were seen, showed some positive cells; in fetuses, these were present in only two out of six cases studied. Medial and distal parts of the epididymis were negative in all cases. The same was true for vas deferens in three adults, while one fetus showed some positive epithelial cells in a proximal vas deferens segment. Seminal vesicles were generally negative; however, of the six cases studied five showed some rare and isolated positive cells scattered throughout the entire epithelium of both seminal vesicles (Figure 4). The prostatic epithelium remained negative in all six cases studied. In the monkey, only rete testis and epididymis have been investigated. Positive cells were detected in the rete in four out of seven cases tested; none was found in the epididymis.

\section{Discussion}

The mean level of PAPP-A in seminal plasma is $-1.5 \mu \mathrm{g} / \mathrm{ml}$ (values ranging from 0.18 to $3.1 \mu \mathrm{g} / \mathrm{ml}$ ) (Bischof $e t$ al., 1983). The level in circulating plasma is $\sim 100 \mathrm{ng} / \mathrm{ml}$ (Bischof $e t$ al., 
A.M.Schindler, A.Dayer and P.Biscthof

Table I. Results of the histochemical localization of PAPP-A reactuve cells in the male genital tract

\begin{tabular}{|c|c|c|c|c|c|}
\hline \multirow[t]{4}{*}{ Organ } & \multicolumn{4}{|c|}{ Number of positive cases/Number of cases studied } & \multirow[t]{4}{*}{ Type of cell positive } \\
\hline & \multicolumn{3}{|c|}{ Human } & \multirow{3}{*}{$\begin{array}{l}\text { Rhesus } \\
\text { monkey } \\
\text { Fetal }\end{array}$} & \\
\hline & Fetal & Infantile & Adult & & \\
\hline & & & & & \\
\hline Testis & $5 / 5$ & $1 / 1$ & $12 / 12$ & $4 / 7$ & Certain Leydig cells \\
\hline Rete testis & $1 / 1$ & - & $6 / 7$ & $4 / 6$ & Certain eprthelial cells \\
\hline Epididymis & $2 / 7$ & - & $10 / 13$ & $1 / 7$ & $\begin{array}{l}\text { Rare epıthelial cells of } \\
\text { proximal tubules }\end{array}$ \\
\hline Vas deferens & $1 / 2$ & - & $0 / 3$ & - & $\begin{array}{l}\text { Some epithelial cells in a } \\
\text { fetus of } 16 \text { weeks }\end{array}$ \\
\hline Seminal vesicle & - & - & $6 / 6$ & - & Certain epithelial cells \\
\hline Prostate & - & - & $0 / 6$ & - & \\
\hline
\end{tabular}
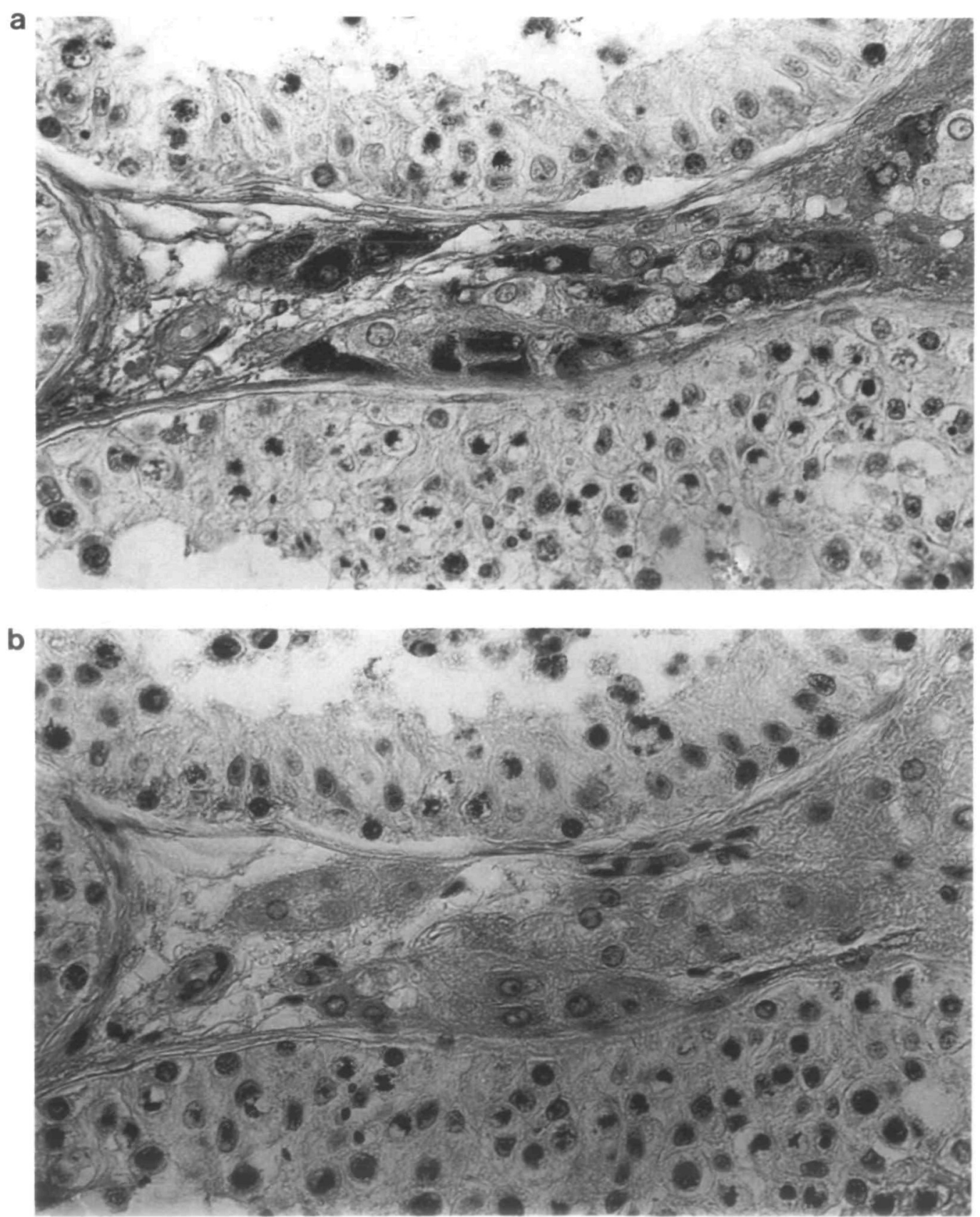

Fig. 1. (a) PAPP-A in Leydig cells of an adult testis, as demonstrated by the PAP-method ( $\times 100)$. (b) No staining of the control section, submitted to absorbed PAPP-A ant-serum $(\times 100)$. 
a

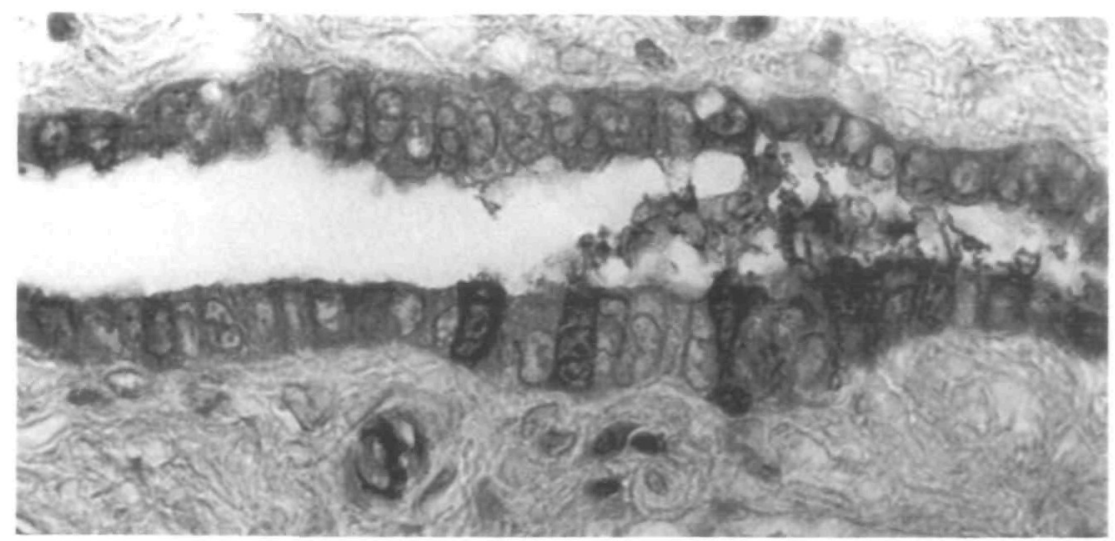

b

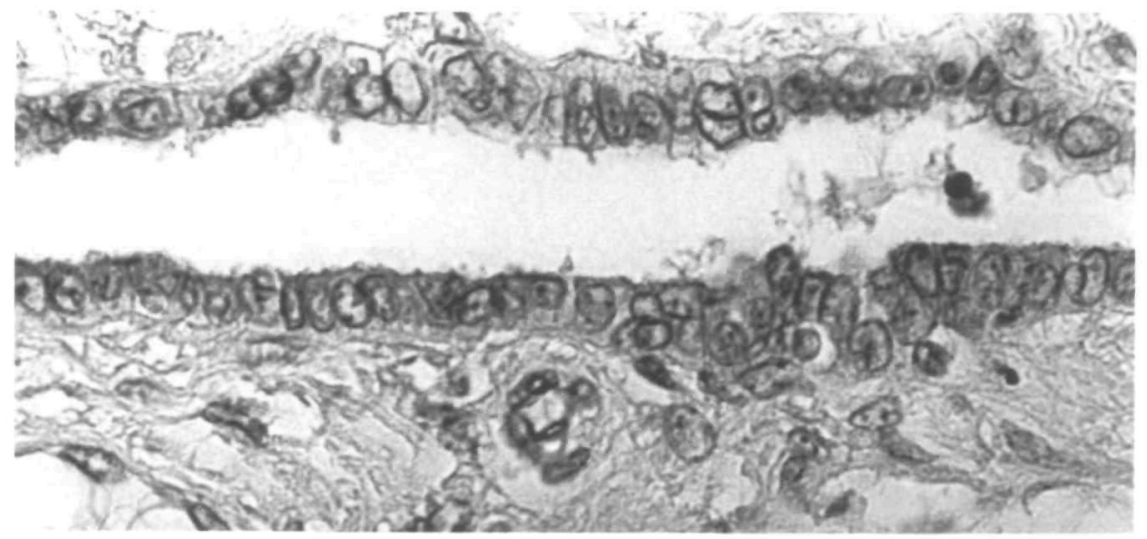

Fig. 2. (a) PAPP-A in epithelial cells of the rete testis, as demonstrated by the PAP-method $(\times 160)$. (b) No staining of the control section submitted to absorbed PAPP-A anti-serum $(\times 160)$.

a

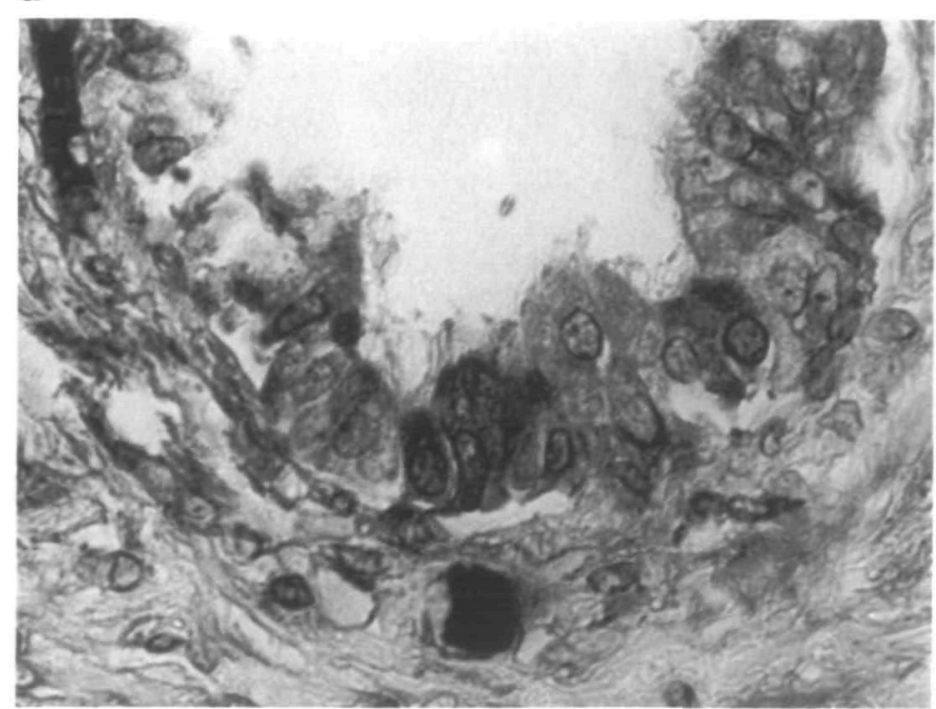

b

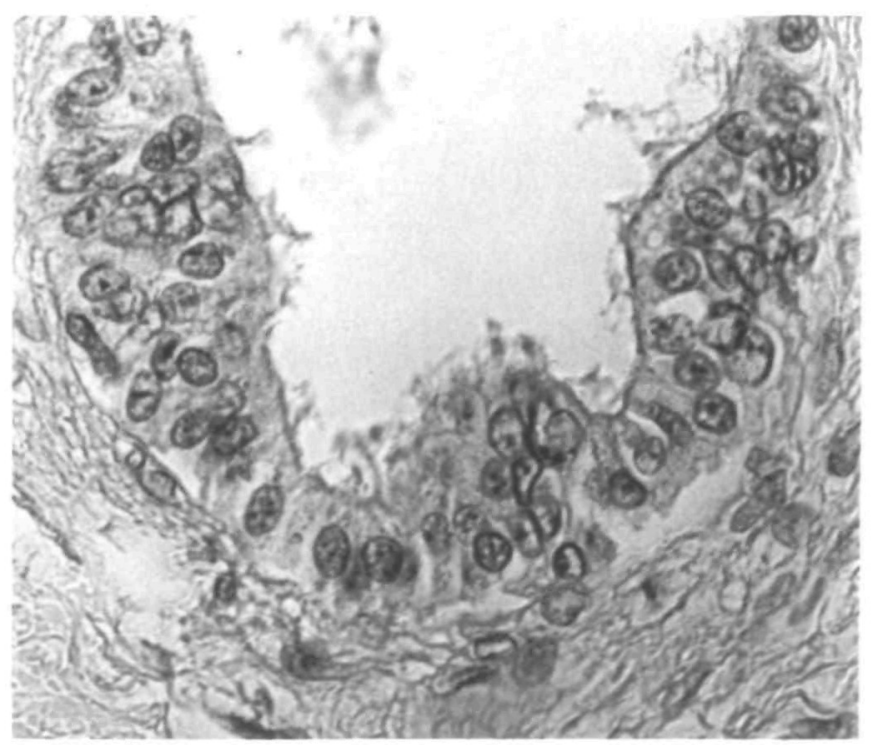

Fig. 3. (a) PAPP-A in epithelial cells of the epididymis testis, as demonstrated by the PAP-method ( $\times 160)$. (b) No staining of the control section submitted to absorted PAPP-A anti-serum ( $\times 160)$.

1982a). There is a 10 to 20 -fold increase in concentration of PAPP-A in the seminal fluid as compared to plasma. This important gradient can be explained either by secretion of PAPP$A$ into the seminal fluid or by an active transfer mechanism, somewhere along the male genital tract. Our morphological studies do show PAPP-A-containing epithelial cells, located in the rete testis, the proximal segments of the epididymis and in the seminal vesicles. The concentration of this protein should be lower in vasectomized men than in normal men, if these cells were the main source of PAPP-A in the seminal fluid, since 
a
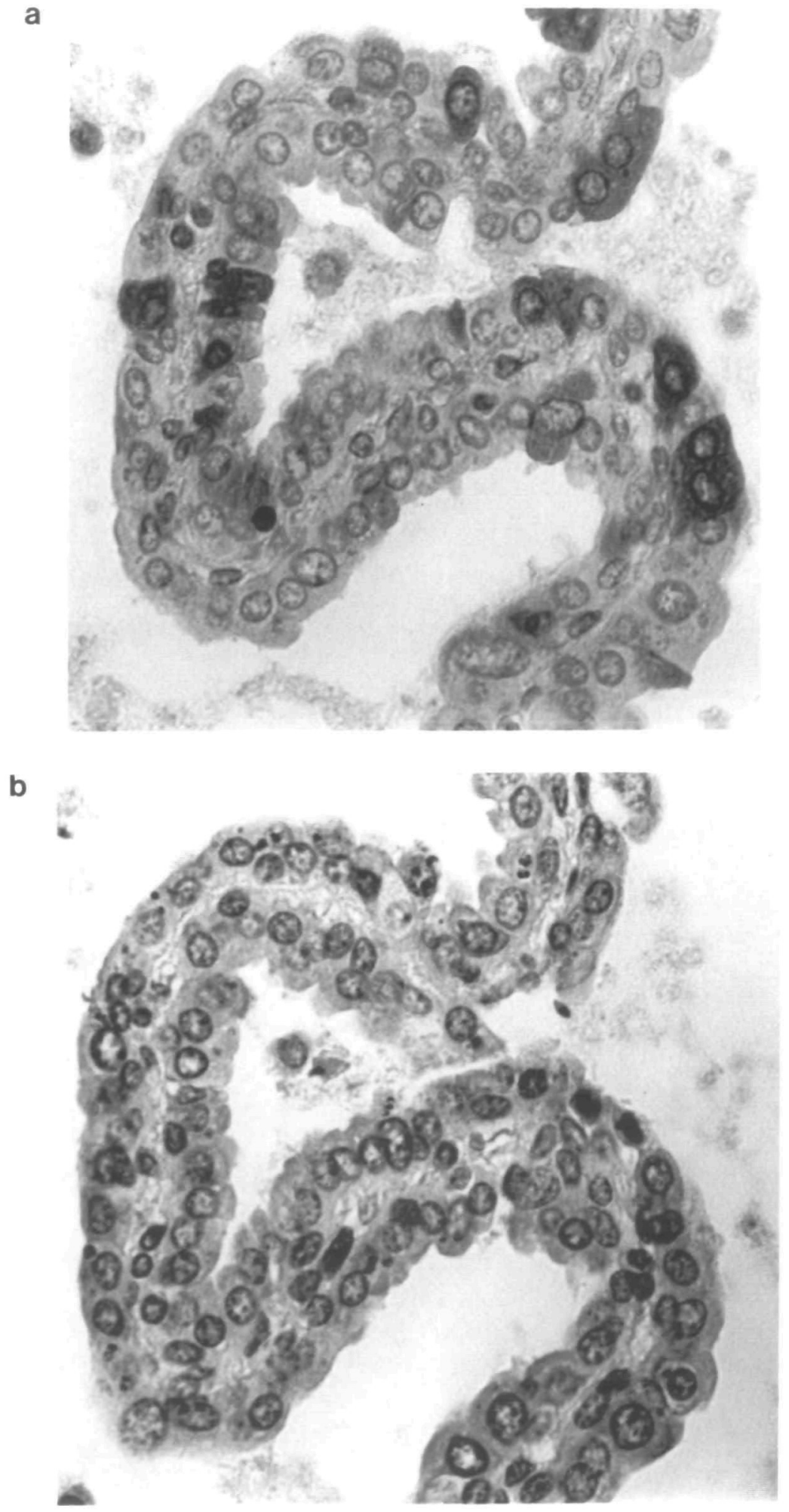

Fig. 4. (a) PAPP-A in epithelial cells of the seminal vesicles, as demonstrated by the PAP-method $(\times 160)$. (b) No staining of the control section submitted to absorbed PAPP-A anti-serum $(\times 160)$.

vasectomy would eliminate the fraction from the rete and from the epididymis. However, vasectomy does not induce any significant change in PAPP-A concentration of the seminal fluid (Bischof et al., 1983).

It is, in addition, questionable if the few positively reacting cells can account for the level of PAPP-A present in seminal fluid. It is, of course, possible that by the immunoperoxidase technique we are unable to reveal the intracellular form of PAPP-A. The sparsity of positive epithelial cells might thus be due to the fact that only a few cells contain the molecule in such a form that the antibody can recognize it.

On the other hand, one can imagine an active transfer of circulating PAPP-A into the seminal fluid. Such a transfer would have to take place along the length of the excretory part of the 
genital tract, since vasectomy does not influence the levels of PAPP-A in the seminal fluid. In the context of such a mechanism, the role of the Leydig cells could possibly be the secretion of PAPP-A into the circulation in order to increase the plasma concentration locally.

The histochemically comparable picture in the rhesus monkey concurs with the knowledge that the PAPP-A of this species is immunologically and chemically comparable, but not identical to the human protein (unpublished results).

In a study published very recently, Sjöberg et al. (1985) confirmed the presence of PAPP-A in seminal fluid, in seminal vesicles and in the vas deferens, but were unable to localize PAPP-A in the epididymis or in the testis. The differences between their observations and ours cannot be explained by the antiserum since both studies used the same one (DAKO). It must thus be considered that the different observations are mainly due to technical differences such as the freshness of the specimen, the type of fixative, etc.

The biological role of PAPP-A is still unknown; this holds for the woman during pregnancy as well as for the male. PAPP-A inhibits PHA-stimulated lymphocytes and might therefore have an immunosuppressive role. Its presence in relatively large amounts in the seminal fluid might serve an immunoprotective role, by coating the surface of the spermatozoa. Preliminary results with immunofluorescence and immunoperoxidase suggest the presence of a thin layer surrounding certain spermatozoa, similar to the one described on the surface of the trophoblast (Schindler et al., 1984).

\section{References}

Bischof,P. (1979) Punfication and characterization of pregnancy-associated plasma protein-A (PAPP-A). Arch. Gynecol., 227, 316-326.

Bischof,P., DuBerg,S., Schindler,A.M., Herrmann, W.L. and Sizonenko,P.C. (1982a) A hypothesis on the biological function of pregnancy-associated plasm protein-A. Pregnancy Proteins. Academic Press, Sydney, pp. 321-332.

Bischof,P., DuBerg,S., Schindler,A.M., Obradovic,D., Weil,A., Faigaux,R., Hermmann,W.L. and Sizonenko,P.C. (1982b) Endometrial and plasma concentrations of pregnancy-associated plasma protein-A (PAPP-A). Br. J. Obstet. Gynaecol., 89, 701-703.

Bischof,P., Martin-du-Pan,R., Lauber,K., Girard,J.P., Hermann, W.L. and Sizonenko,P.C. (1983) Human seminal plasma contains a protein that shows physicochemical, immunochemical and immunosuppressive properties with pregnancy-associated plasma protein-A. J. Clin. Endocnnol. Metab., 56, $359-362$.

Bischof,P., DuBerg,S., Sizonenko,M.T., Schindler,A.M., Béguin,F., Herrmann,W.L. and Sizonenko,P.C. (1984) In vitro production of PAPP-A by human decidua and trophoblast. Am. J. Obstet. Gynecol., 148, 13-19.

Lin,T.M., Halbert,S.P., Kiefer,D., Spellacy,W.N. and Gall,S. (1974) Charactenzation of four human pregnancy-associated plasma proteins. Am. J. Obstet. Gynecol., 118, 223-236.

Lin,T.M., Halbert,S.P. and Kiefer,D. (1976) Quantitative analysis of pregnancyassociated protein in human placenta. J. Clin. Invest., 57, 466-472.

Martin-du-Pan,R., Bischof,P., Bourrit,B., Lauber,K., Girard,J.P. and Herrmann, W.L. (1983) Immunosuppressive activity of seminal plasma and pregnancy-associated plasma protein-A (PAPP-A) in men. Arch. Androl., 10, $185-188$.

McIntyre,J.A., Hsi,B., Faulk, W.P., Klopper, A. and Thomson,R. (1981) Immunological studies of the human placenta: functional and morphological analysis of pregnancy-associated plasma protein-A (PAPP-A). Immunology, 44, $577-583$.

Schindler,A.M., Bordignon,P. and Bischof,P. (1984) Immunohistochemical bocalization of pregnancy-associated plasmea protein- $A$ in decidua and trophoblast. Comparison with hCG and fibrin. Placenta, 5, 227-236.

Sjöberg,J., Wahlsurōm,T., Seppälä,M., Rutanen,E.M., Koistinen,R., Koskimies,A.I., Sinosich,M., Teisner,B. and Grudzinskas,J.G. (1985) Seminal plasma levels of PAPP-A in normospermic and oligospermic men and tissue localization of PAPP-A in the male genital tract. Arch Androl., 14, 253-261.
Stimson, W.H. (1981) Pregnancy-associatod proteins and hormones: do they contribute to the regulation of the maternal immune response in pregnancy? Clin. Immunol. Newsl, 2, 7-11.

Received on 2 December 1985; accepted an 16 Jaunary 1986 